\title{
PENGARUH PENETAPAN HARGA TERHADAP VOLUME PENJUALAN BESI PADA PT. INTI LOGAM PALEMBANG
}

\author{
Oktariansyah*)
}

\begin{abstract}
ABSTRAK
Penelitian ini bertujuan untuk mengetahui apakah ada Pengaruh Penetapan Harga Terhadap Volume Penjualan Besi Pada PT. Inti Logam Palembang. Rumusan masalahnya apakah ada pengaruh penetapan harga terhadap volume penjualan besi pada PT. Inti Logam Palembang. Populasi dalam penelitian ini adalah berdasarkan lamanya waktu atau periode yaitu dari bulan Juni sampai September 2015, sedangkan sampel yang diambil yaitu selama waktu 4 bulan. Penelitian ini adalah termasuk pada penelitian asosiatif. Variabel yang digunakan adalah variabel Penetapan Harga dan Volume Penjualan. Metode pengumpulan data menggunakan wawancara (interview), observasi (pengamatan), dan dokumentasi. Teknik analisis data yang digunakan adalah analisis kuantitatif.

Hasil analisis dari perhitungan analisis regresi linier sederhana diperoleh persamaan $Y=$ $82,994+6,906 \mathrm{X}$ dimana nilai $a=82,994$ dan nilai $b=6,906$ artinya jika harga mengalami kenaikan maka volume penjualan akan mengalami penurunan. Nilai koefisien korelasinya $r_{x y}=0,634$ artinya terdapat hubungan yang kuat dan positif. Hasil uji hipotesis diperoleh $t$-hitung $(2,570)>t_{\text {tabel }}(2,447)$ maka Ho ditolak dan Hi diterima artinya ada pengaruh yang signifikan antara penetapan harga terhadap volume penjualan besi pada PT. Inti Logam Palembang.
\end{abstract}

Kata Kunci : Penetapan Harga, Volume Penjualan.

\section{A. Latar Belakang}

Perusahaan merupakan suatu bentuk organisasi yang pada dasarnya didirikan dengan tujuan untuk memperoleh keuntungan yang sebesar-besarnya dengan cara menyediakan barang atau jasa sesuai dengan keinginan. Dan kebutuhan masyarakat serta saling bersaing satu sama lain, untuk memperoleh daerah pemasaran dengan berbagai cara yang telah disetujui dan ditetapkan bersama melalui sebuah kesepakatan dan perencanaan yang matang.

Dari waktu ke waktu munculnya perusahaan-perusahaan baru yang memiliki produk baru dan menyediakan yang baru, harga, kualitas dan merek yang berbeda. Semakin ketatnya persaingan antar perusahaan yang satu dengan yang lain maka timbul persaingan harga barang, persaingan dianggap sebagai hal yang wajar oleh para pengusaha. Bila perusahaan sadar akan efektifitas, efisiensi dan

*) Dosen Tetap Fakultas Ekonomi UPGRI Palembang kekurangannya perusahaan akan mampu meningkatkan daya saing serta laju perkembangan kegiatan usahanya.

Dalam memasarkan suatu barang atau jasa, setiap perusahaan harus mampu menetapkan harga jual secara tepat. Harga merupakan satu-satunya unsur dari pemasaran yang menghasilkan pendapatan bagi perusahaan. Berhasilnya suatu perusahaan dalam memasarkan produknya dipengaruhi oleh tingkat harga jual yang dikenalkan kepada konsumen, karena harga adalah salah satu faktor yang penting bagi perusahaan untuk meningkatkan dan memperluas pasarnya.

Pada saat menetapkan harga jual perusahaan harus lebih teliti untuk mengambil suatu keputusan agar dalam penjualannya nanti tidak akan mengalami kerugian bagi perusahaan. Dalam mengambil keputusan mengenai kebijakan penetapan harga, perusahaan sebaiknya memperhatikan 
biaya-biaya operasi dalam melakukan aktivitasnya. Karena secara tidak langsung penetapan harga juga dapat mempengaruhi volume penjualan khususnya penjualan besi.

Harga mempunyai peranan yang sangat penting dalam mempengaruhi konsumen untuk membeli atau menggunakan produk atau jasa yang kita tawarkan karena sudut pandang konsumen mengganggap harga sebagai indikator nilai bilamana harga tersebut dihubungkan dengan manfaat yang dirasakan atas suatu barang atau jasa. Menurut Kotler dan Gary Amstrong (2012:345) harga adalah jumlah semua nilai yang diberikan oleh pelanggan untuk mendapatkan keuntungan dari memiliki atau menggunakan suatu produk atau jasa. Agar perusahaan dapat menguasai pasar yang lebih luas perusahaan perlu menetapkan harga yang bersaing dengan kualitas produk yang jauh lebih baik dari produk yang ditawarkan perusahaan pesaing guna mempengaruhi keputusan pembelian konsumen. Harga merupakan nilai suatu barang yang dijual kepada pembeli yang diukur dengan sejumlah uang tertentu sehingga terjadilah suatu transaksi jual beli antara pihak penjual dan pihak pembeli.

Penjualan menurut Buchari (2009:10) yaitu interaksi antara individu, saling bertemu muka yang ditujukan untuk menciptakan, memperbaiki, menguasai atau mempertahankan dengan pihak lain. Dengan tingkat harga bersaing yang merupakan salah satu faktor yang mempengaruhi meningkatnya volume penjualan pada suatu perusahaan.

PT. Inti Logam Palembang merupakan salah satu perusahaan yang menjalankan aktivitasnya di bidang perdagangan umum khususnya perdagangan berbagai jenis besi, seperti Plat, Pipa, Behel, IWF, UNP,
CNP, Wiremesh, As dan lain-lain. Penjualan besi khususnya besi behel ukuran $8 \mathrm{~mm}$ dan $10 \mathrm{~mm}$ dengan jenis KS-Cilegon dikarenakan besi behel merupakan salah satu bahan bangunan yang banyak dipakai dan selalu dibutuhkan setiap ingin membangun rumah ataupun gedunggedung bertingkat serta behel $8 \mathrm{~mm}$ dan $10 \mathrm{~mm}$ (KS-Cilegon) ini paling mendominasi penjualan khususnya penjualan besi behel. Kualitas produk merupakan salah satu usaha yang dipertahankan oleh PT. Inti Logam Palembang sampai sekarang ini agar volume penjualan dapat meningkat sehingga tujuan utama perusahaan yaitu mendapatkan keuntungan yang maksimal dapat tercapai.

PT. Inti Logam Palembang merupakan suatu perusahaan yang melakukan transaksi penjualannya baik dalam jumlah besar maupun kecil dan penjualannya pun tidak hanya pada perorang tetapi juga pada sekelompok orang atau perusahaan yang membeli dalam jumlah besar misalnya perusahaan kontraktor, lembaga-lembaga pemerintah serta toko-toko bangunan.

PT. Inti Logam Palembang merupakan distributor dari penjualan khususnya jenis-jenis besi. Sekarang ini harga penjualan besi sedang mengalami penurunan dan ini berakibat pada meningkatnya permintaan besi sehingga membuat volume penjualan pada perusahaan ini meningkat.

Dari uraian diatas dapat disimpulkan bahwa faktor harga jual merupakan salah satu penyebab meningkatnya penjualan dan hal ini menjadi pertimbangan bagi seseorang atau sekelompok orang pembeli untuk memutuskan membeli besi behel atau tidak membeli. 


\section{B. Rumusan Masalah}

"Apakah Terdapat Pengaruh Penetapan Harga Terhadap Volume Penjualan Besi Behel pada PT. Inti Logam Palembang?"

\section{Landasan Teori}

\section{1) Pengertian Pemasaran}

Menurut Kotler dan Keller (2009:5) menyatakan Pemasaran adalah sebuah proses kemasyarakatan di mana individu dan kelompok memperoleh apa yang mereka butuhkan dan inginkan dengan menciptakan, menawarkan, dan secara bebas mempertukarkan produk dan jasa yang bernilai dengan orang lain.

Menurut William J. Stanton dalam Basu Swastha dan Irawan (2009:7) menyatakan bahwa Pemasaran adalah suatu sitem keseluruhan dari kegiatankegiatan bisnis yang ditujukan untuk merencanakan, menentukan harga, mempromosikan, dan mendistribusikan barang dan jasa yang memuaskan kebutuhan baik kepada pembeli yang ada maupun pembeli potensial.

Berdasarkan definisi tersebut diatas dapat disimpulkan bahwa pemasaran merupakan suatu interaksi yang berusaha menciptakan hubungan pertukaran dengan suatu sistem tertentu, serta kegiatan pemasaran merupakan keseluruhan kegiatan bisnis dan cara untuk menghasilkan laba bagi perusahaaan.

\section{2) Bauran Pemasaran}

Sebelum melaksanakan kegiatan pemasaran produk yang dihasilkan, sebuah perusahaan harus terlebih dahulu memperhatikan beberapa hal yang cukup penting dalam menunjang keberhasilan penjualan yaitu bauran pemasaran.

Menurut Kotler dan Armstrong (2012:75) Bauran pemasaran (marketing mix) adalah seperangkat alat pemasaran terkontrol yang dipadukan oleh perusahaan untuk menghasilkan respon yang diinginkan pasar sasaran. Menurut Kotler dan Armstrong bauran pemasaran dapat dikelompokkan kedalam empat variabel yaitu produk (product), harga (price), tempat (place), promosi (promotion) yang akan dijelaskan satu persatu sebagai berikut :

a) Produk (product)

Produk adalah segala sesuatu yang dapat ditawarkan ke pasar untuk mendapatkan perhatian, dibeli, dipergunakan, atau dikonsurnsi dan yang dapat memuaskan keinginan atau kebutuhan. produk mencakup objek secara fisik, jasa, orang, tempat, organisasi, dan ide.

b) Harga (price)

Salah satu komponen dari bauran pemasaran adalah harga. Harga adalah sejumlah uang yang dibutuhkan untuk mendapatkan sejumlah kombinasi dari produk dan pelayanannya. Didalam penetapan tingkat harga yang tepat perusahaan harus mempertimbangkan keadaan persaingan pasar, jika harga jual lebih tinggi dari harga saingan maka produk yang ditawarkan akan sedikit atau mungkin tidak terjual sama sekali, dan apabila produk dijual dibawah harga para pesaing, maka produk mungkin akan banyak terjual tetapi keuntungan yang diharapkan belum ientu tercapai.

c) Tempat (place)

Meliputi kegiatan perusahaan yang membuat produk tersedia bagi pelanggan sasaran. Oleh karena itu tempat merupakan komponen yang tak kalah pentingnya dari komponen bauran pemasaran yang lainnya. Penggunaan saluran distribusi yang efcktif akan sangat menunjang kegiatan pemindahan barang dari produsen ke konsumen, dan sebaliknya 
penggunaan saluran ditribusi yang tidak efektif akan menghambat penyaluran barang dari produsen ke konsumen.

d) Promosi (promotion) Merupakan aktivitas yang menyampaikan manfaat produk dan membujuk pelanggan membelinya. Promosi merupakan salah satu kegiatan dibidang pemasaran yang bertujuan untuk meningkatkan volume penjualan dengan jalan mempengaruhi konsumen baik secara langsung maupun tidak langsung. Promosi termasuk salah satu faktor yang dapat mempengaruhi tingkat penjualan dan merupakan variabel yang dapat dikendalikan oleh perusahaan, melalui promosi diharapkan konsumen atau calon konsumen dapat mengenal produk yang dihasilkan dan ditawarkan sehingga masyarakat tertarik dan akhirnya mencoba produk tersebut.

Jadi dapat disimpulkan bahwa bauran pemasaran merupakan faktor yang sangat penting dan mendukung dalam kegiatan pemasaran.

\section{3) Pengertian Harga}

Salah satu komponen dari bauran pemasaran adalah harga. Harga adalah sejumlah uang yang dibutuhkan untuk mendapatkan sejumlah kombinasi dari produk dan pelayanannya.

Menurut Swastha (2010:147) Harga adalah jumlah uang (ditambah beberapa barang kalau mungkin) yang dibutuhkan untuk mendapatkan sejumlah kombinasi dari barang beserta pelayanannya.

Sedangkan menurut Alma (2009:169) harga (price) adalah nilai suatu barang yang dinyatakan dengan uang.

Dari pengertian harga di atas dapat disimpulkan bahwa keberhasilan suatu perusahaan dalam memasarkan produknya dipengaruhi oleh tingkat harga jual yang di kenaikan kepada konsumen. Harga merupakan salah satu faktor yang penting bagi perusahaan untuk meningkatkan dan memperluas pasarnya.

\section{4) Tujuan Penetapan Harga}

Pada dasarnya ada lima jenis tujuan penetapan harga menurut Kotler dan Keller (2009:76), yaitu sebagai berikut :

a) Kemampuan bertahan

Perusahaan mengejar kemampuan bertahan sebagai tujuan utama mereka jika mereka mengalami kelebihan kapasitas, persaingan ketat, atau keinginan konsumen yang berubah. Selama harga menutup biaya variabel dan biaya tetap maka perusahaan tetap berada dalam bisnis.

b) Laba saat ini maksimum

Banyak perusahaan berusaha menetapkan harga yang akan memaksimalkan laba saat ini. Perusahaan memperkirakan permintaan dan biaya yang berasosiasi dengan harga alternatif dan memilih harga yang menghasilkan laba saat ini, arus kas, atau tingkat pengembalian atas investasi maksimum.

c) Pangsa Pasar Maksimum

Perusahaan percaya bahwa semakin tinggi volume penjualan, biaya unit akan semakin rendah dan laba jangka panjang semakin tinggi. Perusahaan menetapkan harga terendah mengasumsikan pasar sensitif terhadap harga. Strategi penetapan harga penetrasi pasar dapat diterapkan dalam kondisi :

1. Pasar sangat sensitif terhadap harga dan harga yang rendah merangsang pertumbuhan pasar. 
2. Biaya produksi dan distribusi menurun seiring terakumulasinya pengalaman produksinya

3. Harga rendah mendorong persaingan aktual dan potensial.

d) Market Skiming Pricing

Perusahaan mengungkapkan teknologi baru yang menetapkan harga tinggi untuk memaksimalkan memerah pasar dimana pada mulanya harga ditetapkan tinggi dan secara perlahan turun seiring waktu. Skiming pricing digunakan dalam kondisi sebagai berikut :

1. Terdapat cukup banyak pembeli yang permintaan saat ini yang tinggi.

2. Biaya satuan memproduksi volume kecil tidak begitu tinggi hingga menghilangkan keuntungan dari mengenakan harga maksimum yang mampu diserap pasar.

3. Harga awal tinggi menarik lebih banyak pesaing kepasar.

4. Harga tinggi mengkomunikasikan citra produk yang unggul

e) Kepemimpinan kualitas produk.

Banyak merek berusaha menjadi "kemewahan terjangkau" produk atau jasa yang ditentukan karakternya oleh tingkat kualitas anggapan, selera dan status yang tinggi dengan harga yang cukup tinggi agar tidak berada diluar jangkauan konsumen.

Tujuan-tujuan penetapan harga diatas memiliki implikasi penting terhadap strategi bersaing perusahaan. Tujuan yang ditetapkan harus konsisten dengan cara yang ditempuh peusahaan dalam menempatkan posisi relatifnya dalam persaingan.

\section{5) Prosedur Penetapan Harga}

Menurut Kotler dan Keller (2009:83), ada enam metode penetapan harga adalah sebagai berikut :

a) Penetapan Harga Markup

Metode penetapan harga paling mendasar adalah menambah markup standar ke biaya produk. Sampai saat ini penetapan harga markup masih populer karena penjual dapat menentukan biaya jauh lebih mudah dari pada memperkirakan permintaan, kemudian harga cenderung sama dan persaingan harga terminimalisasi ketika perusahaan dalam industri mengunakan metode ini, dan terakhir banyak orang merasa bahwa penetapan harga biaya plus lebih adil bagi pembeli dan penjual.

b) Penetapan harga tingkat pembelian sasaran

Perusahaan menentukan harga yang akan menghasilkan tingkat pengembalian atas investasi sasarannya.

c) Penetapan harga nilai anggapan

Nilai anggapan terdiri dari beberapa elemen seperti citra pembeli akan kinerja produk, kemampuan penghantaran dari saluran, kualitas jaminan, dukungan pelanggan, dan atribut yang kurang dominan seperti reputasi pemasok, ketepercayaan dan harga diri.

d) Penetapan harga nilai

Metode yang menciptakan harga murah kepada konsumen untuk menarik perhatian konsumen dengan tidak mengabaikan kualitas produk perusahaan.

e) Penetapan harga going-rate

Perusahaan mendasarkan sebagian besar harganya pada harga pesaing, mengenakan harga yang sama, lebih mahal atau lebih murah dibandingkan harga pesaing utama. 
f) Penetapan harga jenis lelang

Penetapan harga jenis lelang

dilakukan untuk membuang

persediaan lebih atau barang

bekas.

Suatu perusahaan harus menetapkan harga untuk pertama kali ketika perusahaan mengembangkan atau memperoleh suatu produk baru, memperkenalkan produk ke saluran distribusi atau daerah baru, dan ketika perusahaan akan mengikuti lelang atas suatu kontrak kerja baru. Hal tersebut dilakukan agar tujuan perusahaan dapat tercapai.

\section{6) Pengertian Penjualan}

Menurut Soemarso (2009:160)

Penjualan adalah jumlah yang dibebankan kepada pembeli untuk barang dagang yang diserahkan merupakan pendapatan perusahaan yang bersangkutan.

Sedangkan menurut William G. Nickels dalam Basu Swastha (2009:10) Penjualan tatap muka adalah interaksi antar individu, saling bertemu muka yang ditujukan untuk menciptakan, memperbaiki, menguasai atau mempertahankan hubungan pertukaran yang saling menguntungkan dengan pihak lain.

Berdasarkan pengertian di atas, maka dapat disimpulkan bahwa penjualan adalah persetujuan kedua belah pihak antara penjual dan pembeli, dimana penjual menawarkan suatu produk dengan harapan pembeli dapat menyerahkan sejumlah uang sebagai alat ukur produk tersebut sebesar harga jual yang telah disepakati.

\section{7) Jenis-Jenis Penjualan}

Menurut Swastha (2009:11) jenisjenis penjualan dapat dikelompokkan sebagai berikut: a) Trade selling

Trade selling dapat terjadi bilamana produsen dan pedagang besar mempersilakan para pengecer untuk berusaha memperbaiki distributor produkproduk mereka.

b) Missionary selling

Penjualan berusaha ditingkatkan dengan mendorong pembeli untuk membeli barang-barang dari penyalur perusahaan.

c) Technical selling

Technical selling berusaha meningkatkan penjualan dengan pemberian saran dan nasehat kepada pembeli akhir dari barang dan jasanya.

d) New business selling

Berusaha membuka transaksi baru dengan merubah calon pembeli menjadi pembeli.

e) Responsiv selling

Setiap tenaga penjualan diharapkan dapat memberikan reaksi terhadap permintaan pembeli.

\section{8) Tahapan-Tahapan Penjualan}

Menurut Swastha (2009:122) tahapan-tahapan penjualan adalah sebagai berikut:

a) Persiapan sebelum penjualan

Tahap pertama yang dilakukan adalah mempersiapkan tenaga penjualan dengan memberikan pengertian tentang barang yang akan dijual, pasar yang dituju dan teknik-teknik penjualan yang harus dilakukan serta mereka harus mengetahui tentang motivasi dan perilaku segmen pasar yang dituju.

b) Penentuan lokasi pembeli potensial Pada tahap kedua ini ditentukan lokasi segmen pasar yang menjadi sasarannya sehingga dapat diketahui dengan logis pembeli potensial dari produk yang ditawarkan. 
c) Pendekatan pendahuluan

Pada tahap ini sebelum melakukan penjualan, penjual harus mengumpulkan berbagai informasi untuk mendukung penawaran produknya kepada pembeli misalnya kebiasaan pembeli, kesukaan dan sebagainya.

d) Melakukan penjualan

Penjualan dilakukan bermula dari suatu usaha untuk memikat perhatian calon konsumen kemudian diusahakan untuk mengetahui minat mereka.

e) Pelayanan purna jual

Dalam tahap akhir ini penjual harus berusaha mengatasi berbagai macam keluhan atau tanggapan yang kurang baik dari pembeli serta memberikan jaminan bahwa keputusan yang diambil tepat dan barang yang dibeli bermanfaat.

\section{9) Volume Penjualan}

Pengertian volume penjualan menurut Swastha dan Irawan (2008:141) Volume penjualan merupakan suatu studi mendalam tentang masalah "penjualan bersih" dari laporan rugi-laba perusahaan (laporan operasi). Manajemen perlu menganalisa volume penjualan total, dan juga volume itu sendiri. Analisa tersebut dapat didasarkan pada:

$>$ Product line

> Segmen pasar (teritorial, kelompok pembeli dan sebagainya)

Berdasarkan dari pengertian diatas dapat ditarik sebuah kesimpulan bahwa volume penjulan merupakan hasil dari kegiatan penjualan yang dilakukan perusahaan dalam usahanya mencapai sasaran yaitu memaksimalkan laba.

\section{Metode Penelitian}

Penelitian ini adalah jenis penelitian asosiatif yaitu suatu pertanyaan peneliti yang bersifat menanyakan hubungan antara dua variabel atau lebih. Adapun variabel yang dimaksud dalam penelitian ini adalah penetapan harga dan volume penjualan Sugiyono (2009:55).

\section{E. Populasi dan Sampel}

1. Populasi Penelitian Populasi menurut Sugiyono (2009:115) adalah wilayah generalisasi yang terdiri atas objek/subyek yang mempunyai kualitas dan karakteristik tertentu yang ditetapkan oleh peneliti untuk dipelajari dan kemudian ditarik kesimpulannya, maka populasinya adalah berdasarkan lamanya waktu atau periode dari bulan Juni sampai September 2015.

2. Sampel Penelitian

Sampel menurut Sugiyono (2009:116) adalah bagian dari jumlah dan karakteristik yang dimiliki oleh populasi tersebut. Bila populasi besar dan peneliti tidak mungkin mempelajari semuanya, maka peneliti dapat menggunakan sampel yang diambil dari populasi. Jadi sampel yang diambil adalah selama waktu 4 bulan.

\section{F. Teknik Pengumpulan Data}

Bungin (2010:126) menyatakan bahwa teknik pengumpulan data adalah sebagai berikut :

1) Wawancara atau interview

Sebuah proses memperoleh keteranagan untuk tujuan penelitian dengan cara tanya jawab sambil bertatap muka antara pewawancara responden atau orang yang diwawancarai, dengan atau tanpa menggunakan pedoman (guide) wawancara.

2) Observasi atau pengamatan

kemampuan seseorang untuk menggunakan pengamatannya melalui hasil kerja pancaindra mata serta dibantu dengan pancaindra lainnya. 
3) Dokumenter

Metode yang digunakan untuk menelusuri data historis.

\section{F. Teknik Analisis Data}

Teknik analisis yang digunakan dalam penelitian ini adalah analisis kuantitatif yaitu suatu metode analisis dengan menggunakan perhitungan angka-angka guna menagambil suatu keputusan. Dalam penelitian ini penulis menggunakan analisis regresi sederhana, koefisien korelasi, uji hipotesis dan koefisien diterminasi.

\section{1) Analisis \\ Sederhana}

Regresi

Linier

Menurut Riduan dan Akdon (2009:133) regresi sederhana digunakan untuk meramalkan atau memprediksi variabel terikat $(Y)$ apabila variabel bebas (X) diketahui. Persamaan regresi dirumuskan :

$$
\begin{aligned}
& \text { Dimana : } \hat{\mathbf{Y}}=\boldsymbol{a}+\boldsymbol{b} \mathbf{x} \\
& \hat{Y}=\text { Subjek Variabel Terikat Yang } \\
& \text { Diproyeksikan }
\end{aligned}
$$

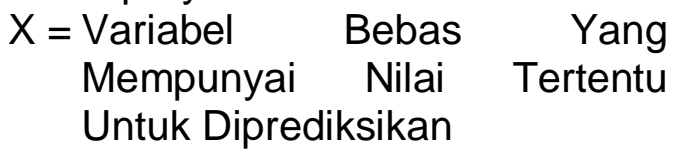

$$
\begin{aligned}
& a=\text { Nilai Konstanta Harga } Y \text { Jika } X \\
& =0 \\
& \text { b = Nilai Arah Sebagai Penentu } \\
& \text { Ramalan (Prediksi) Yang } \\
& \text { Menunjukkan Nilai Peningkatan } \\
& (+) \text { atau Nilai Penurunan (-) } \\
& \text { Variabel } Y
\end{aligned}
$$

Sedangkan untuk mencari nilai a dan $b$ digunakan rumus sebagai berikut :

$$
\begin{aligned}
& b=\frac{n \cdot \sum \mathrm{XY}-\sum \mathrm{X} \cdot \sum \mathrm{Y}}{n \cdot \sum \mathrm{X}^{2}-\left(\sum \mathrm{X}\right)^{2}} \\
& a=\frac{\sum \mathrm{Y}-b \cdot \sum \mathrm{X}}{n}
\end{aligned}
$$

\section{2) Analisis Koefisien Korelasi}

Menurut Riduan dan Akdon (2009:123) teknik ini digunakan untuk mengetahui derajat hubungan antara variabel bebas (independent) dengan variabel terikat (dependent).

$$
\mathbf{r}_{\mathbf{x y}}=\frac{n\left(\sum \mathrm{XY}\right)-\left(\sum \mathrm{X}\right)\left(\sum \mathrm{Y}\right)}{\sqrt{\left\{n \cdot \sum \mathrm{X}^{2}-\left(\sum \mathrm{X}\right)^{2}\right\}\left\{n \cdot \sum \mathrm{Y}^{2}-\left(\sum \mathrm{Y}\right)^{2}\right\}}}
$$

Dimana:

$r_{x y}:$ Koefisien KorelasiValiditas

$x$ : Skor Butir

$y$ : Skor Total

$x^{2}$ : Kuadrat Skor Butir

$y^{2}$ : Kuadrat Skor Butir

$n$ : Jumlah Responden

Korelasi PPM dilambangkan ( $r$ ) dengan ketentuan nilai $r$ tidak lebih dari harga $(-1 \leq r \leq+1)$. Apabila nilai $r=-1$ artinya korelasinya negatif sempurna; $r=0$ artinya tidak ada korelasi; dan $r=1$ berarti korelasinya sangat kuat. Sedangkan arti harga $r$ akan dikonsultasikan dengan Tabel interpretasi Nilai r sebagai berikut :

\section{Tabel 1}

Interpretasi Koefisien Korelasi Nilai r

\begin{tabular}{|c|c|}
\hline $\begin{array}{c}\text { Interval } \\
\text { Koefisien }\end{array}$ & $\begin{array}{c}\text { Tingkat } \\
\text { Hubungan }\end{array}$ \\
\hline $0,80-1,000$ & Sangat Kuat \\
$0,60-0,799$ & Kuat \\
$0,40-0,599$ & Cukup Kuat \\
$0,20-0,399$ & Rendah \\
$0,00-0,199$ & Sangat Rendah \\
\hline
\end{tabular}

\section{3) Uji Hipotesis}

Untuk mengkaji hipotesis bahwa penetapan harga mempunyai pengaruh yang positif terhadap peningkatan volume penjualan maka digunakan uji t. Riduan dan Akdon (2009:125). 


$$
\mathrm{t}=\frac{\mathrm{r} \sqrt{\mathrm{n}-2}}{\sqrt{1-\mathrm{r}}}
$$

Dimana :

$\mathrm{t}=\mathrm{t}_{\text {hitung }}$

$r=$ Koefisien Korelasi

$\mathrm{n}=$ jumlah Sampel

$\mathrm{H}_{\mathrm{i}}$ : Ada pengaruh yang signifikan antara penetapan harga terhadap volume penjualan besi pada PT. Inti Logam Palembang

$\mathrm{H}_{\mathrm{o}}$ : Tidak ada pengaruh yang signifikan antara penetapan harga terhadap volume penjualan besi pada PT. Inti Logam Palembang

$\mathrm{H}_{\mathrm{o}}$ ditolak dan $\mathrm{H}_{\mathrm{i}}$ diterima apabila $t_{\text {-hitung }}>$ dari t-tabel

$\mathrm{H}_{\mathrm{o}}$ diterima dan $\mathrm{H}_{\mathrm{i}}$ ditolak apabila t-hitung $<$ dari t-tabel

\section{4) Koefisien Determinasi}

Untuk menyatakan besar kecilnya sumbangan variabel $\mathrm{X}$ terhadap $\mathrm{Y}$ dapat ditentukan dengan rumus koefisien determinan. (Riduan dan Akdon 2009:124)

\begin{tabular}{l}
$\mathbf{K P}=\mathbf{r}^{\mathbf{2}} \mathbf{x} \mathbf{1 0 0 \%}$ \\
\hline Dimana: \\
$\mathrm{KP}=$ Nilai Koefisien Diterminan \\
$\mathrm{R}=$ Nilai Koefisien Korelasi
\end{tabular}

\section{G. Hasil Penelitian}

Pada bab ini akan dibahas mengenai pengaruh penetapan harga terhadap volume penjualan besi pada PT. Inti Logam Palembang. Untuk mengetahuinya dilakukan perhitungan dengan menggunakan analisis regresi linier sederhana. Analisis regresi linier sederhana digunakan untuk mengetahui seberapa besar pengaruh harga $(X)$ terhadap volume penjualan (Y). Sebelum kedua variabel tersebut diuji, maka variabel-variabel tersebut harus dianalisis terlebih dahulu. Berdasarkan data tabel 2 yang didapat dari PT. Inti Logam Palembang yaitu harga dan volume penjualan besi adalah sebagai berikut :

Tabel 2

Data Harga dan Volume Penjualan Besi

Bulan Juni - September 2015

\begin{tabular}{|c|c|c|c|c|}
\hline No & Bulan & Ukuran & Harga (X) & $\begin{array}{c}\text { Volume Penjualan } \\
(\mathbf{Y})\end{array}$ \\
\hline 1. & Juni & $8 \mathrm{~mm}$ & Rp. 42.000 & 500 \\
\hline 2. & Juli & $8 \mathrm{~mm}$ & Rp. 44.500 & 450 \\
\hline 3. & Agustus & $8 \mathrm{~mm}$ & Rp. 45.000 & 320 \\
\hline 4. & September & $8 \mathrm{~mm}$ & Rp. 46.000 & 250 \\
\hline
\end{tabular}




\begin{tabular}{|c|c|c|c|c|}
\hline No & Bulan & Ukuran & Harga (X) & $\begin{array}{c}\text { Volume Penjualan } \\
(\mathbf{Y})\end{array}$ \\
\hline 1 & Juni & $10 \mathrm{~mm}$ & Rp. 69.000 & 750 \\
\hline 2 & Juli & $10 \mathrm{~mm}$ & Rp. 70.000 & 550 \\
\hline 3 & Agustus & $10 \mathrm{~mm}$ & Rp. 70.500 & 500 \\
\hline 4 & September & $10 \mathrm{~mm}$ & Rp. 71.000 & 500 \\
\hline
\end{tabular}

Sumber : PT.Inti Logam Palembang

Pada data diatas menunjukkan jumlah data yang diambil selama 4 periode, pada dua jenis ukuran besi yaitu behel $8 \mathrm{~mm}$ dan $10 \mathrm{~mm}$ sehingga jumlah datanya adalah 8 . Kemudian dari data tersebut dapat dilakukan perhitungan pengujian pengaruh penetapan harga terhadap volume penjualan besi pada PT. Inti Logam
Palembang, sehingga dari hasil perthitungan kedua variabel tersebut dapat diketahui data untuk perhitungan analisis data selanjutnya. Hasil perhitungan pengujian pengaruh penetapan harga terhadap volume penjualan pada PT. Inti Logam Palembang adalah sebagai berikut :

TABEL 3

Hasil Pengolahan Penetapan Harga (X) dan Volume Penjualan (Y)

\begin{tabular}{|c|c|c|c|c|c|}
\hline No & $\mathbf{X}$ & $\mathbf{Y}$ & $\mathbf{X . Y}$ & $\mathbf{X}^{\mathbf{2}}$ & $\mathbf{Y}^{\mathbf{2}}$ \\
\hline 1 & 42 & 500 & 21000 & 1764 & 250000 \\
\hline 2 & 44 & 450 & 19800 & 1936 & 202500 \\
\hline 3 & 45 & 320 & 14400 & 2025 & 102400 \\
\hline 4 & 46 & 250 & 11500 & 2116 & 62500 \\
\hline 5 & 69 & 750 & 51750 & 4761 & 562500 \\
\hline 6 & 70 & 550 & 38500 & 4900 & 302500 \\
\hline 7 & 70 & 500 & 35000 & 4900 & 250000 \\
\hline 8 & 71 & 500 & 35500 & 5041 & 250000 \\
\hline$\Sigma$ & $\mathbf{4 5 7}$ & $\mathbf{3 8 2 0}$ & $\mathbf{2 2 7 4 5 0}$ & $\mathbf{2 7 4 4 3}$ & $\mathbf{1 9 8 2 4 0 0}$ \\
\hline
\end{tabular}

Sumber : Hasil olahan data sekunder

Berdasarkan hasil perhitungan koefisien antara variabel penetapan harga $(X)$ dan variabel volume penjualan (Y) diatas didapat hasil sebagai berikut :

$$
\begin{aligned}
n & =8 \\
\sum X & =457 \\
\sum Y & =3820 \\
\sum X . Y & =227450
\end{aligned}
$$

$\sum X^{2}=27443$

$\sum Y^{2}=1982400$

1. Analisis Regresi Linier Sederhana

Berdasarkan data sekunder diatas, penulis akan menganalisis dengan analisis kuantitatif yaitu dengan perhitungan regresi linier sederhana. Perhitungan regresi linier sederhana ini 
akan menunjukkan seberapa besar pengaruh anatara variabel $X$ yaitu penetapan harga terhadap variabel $Y$ yaitu volume penjualan. Menurut Riduan dan Akdon (2009:133) rumus regresi linier sederhana yaitu $\hat{Y}=a+b x$. Sedangkan untuk mencari nilai $a$ dan $b$ digunakan rumus sebagai berikut :

\begin{tabular}{l}
\hline$b=\frac{n \cdot \sum \mathrm{XY}-\sum \mathrm{X} \cdot \sum \mathrm{Y}}{n \cdot \sum \mathrm{X}^{2}-\left(\sum \mathrm{X}\right)^{2}}$ \\
\hline \hline$a=\frac{\sum \mathrm{Y}-b \cdot \sum \mathrm{X}}{n}$ \\
Dimana: \\
$\hat{\mathrm{Y}}:$ Penetapan Harga \\
$\mathrm{X}:$ Volume Penjualan \\
$a:$ Nilai Konstanta Harga $\mathrm{Y}$ Jika $\mathrm{X}=0$ \\
$b:$ Koefisien Regresi \\
$\mathrm{n}:$ Jumlah Sampel
\end{tabular}

Dari tabel 3 dapat dihitung nilai $a$ dan $b$ sebagai berikut:

Diketahui:

$\mathrm{n}=8$

$\sum X=457$

$\sum Y=3820$

$\sum X . Y=227450$

$\sum X^{2}=27443$

$\sum Y^{2}=1982400$

\section{Penyelesaian :}

Persamaan regresi nilai $b$ dihitung sebagai berikut :

$$
\begin{aligned}
b & =\frac{n \cdot \sum \mathrm{XY}-\sum \mathrm{X} \cdot \sum \mathrm{Y}}{n \cdot \sum \mathrm{X}^{2}-\left(\sum \mathrm{X}\right)^{2}} \\
& =\frac{8 \cdot(227450)-(457)(3820)}{8(27443)-(457)^{2}} \\
& =\frac{1818600-1745740}{219544-208849} \\
& =\frac{73860}{10695}=6,906
\end{aligned}
$$

Persamaan regresi nilai a dihitung sebagai berikut :

$$
a=\frac{\sum \mathrm{Y}-b \cdot \sum \mathrm{X}}{n}
$$

$$
\begin{aligned}
& =\frac{3820-(6,906)(457)}{8} \\
& =\frac{3820-3156,042}{8}=\frac{663,958}{8}=82,994
\end{aligned}
$$

Setelah nilai $a$ dan $b$ ditemukan, maka persamaan regresi linier sederhana yang didapat adalah $\mathrm{Y}=$ $82,994+6,906 \mathrm{X}$

Berdasarkan

perhitungan persamaan regresi linier sederhana diatas diperoleh nilai konstanta atau a adalah 82,994 dan nilai koefisien regresi atau $b$ adalah 6,906 . Nilai $b$ yang merupakan koefisien regresi sederhana yang mengukur besarnya perubahan variabel (Y) terhadap perubahan variabel $(\mathrm{X})$. Dari persamaan regresi linier sederhana yaitu $\mathrm{Y}=82,994+6,906 \mathrm{X}$ menunjukkan adanya pengaruh antara penetapan harga $(X)$ terhadap volume penjualan (Y) positif. Artinya jika variabel harga $(X)$ mengalami kenaikan Rp. 1 maka variabel volume penjualan (Y) akan turun sebesar Rp. 6,906 dan sebaliknya jika variabel harga (X) mengalami penurunan Rp. 1 maka variabel volume penjualan (Y) akan naik sebesar Rp. 6,906.

\section{Koefisien Korelasi}

Menurut Riduan dan Akdon (2009:123) teknik ini digunakan untuk mengetahui derajat hubungan antara variabel bebas (independent) dengan variabel terikat (dependent). Persamaan korelasi dirumuskan :

$$
r_{x y}=\frac{n\left(\sum X Y\right)-\left(\sum X\right)\left(\sum \mathrm{Y}\right)}{\sqrt{\left\{n \cdot \sum \mathrm{X}^{2}-\left(\sum \mathrm{X}\right)^{2}\right\}\left\{n \cdot \sum \mathrm{Y}^{2}-\left(\sum \mathrm{Y}\right)^{2}\right\}}}
$$

Dimana:

$r_{\mathrm{xy}} \quad$ : Koefisien Korelasi Validitas

$x \quad$ : Skor Butir

$y \quad$ : Skor Total

$x^{2} \quad$ : Kuadrat Skor Butir

$y^{2} \quad$ : Kuadrat Skor Butir

$n \quad:$ Jumlah Responden 
Nilai koefisien korelasi $r$ dapat bervariasi dari -1 sampai +1 dengan ketentuan sebagai berikut :

1. Bila $r=0$ atau mendekati 0 , maka hubungan kedua variabel sangat lemah atau tidak terdapat hubungan sama sekali.

2. Bila $r=-1$ atau mendekati -1 , maka hubungan antara kedua variabel berlawanan, artinya bila $X$ bertambah besar maka $\mathrm{Y}$ bertambah kecil.

3. Bila $r=+1$ mendekati +1 , maka hubungan antar kedua variabel searah, artinya bila $X$ bertambah besar maka $Y$ bertambah besar.

\section{Penyelesaian :}

Koefisien korelasi

$$
\begin{aligned}
& r_{\mathrm{xy}}=\frac{n\left(\sum \mathrm{XY}\right)-\left(\sum \mathrm{X}\right)\left(\sum \mathrm{Y}\right)}{\sqrt{\left\{n \cdot \sum \mathrm{X}^{2}-\left(\sum \mathrm{X}\right)^{2}\right\}\left\{n \cdot \sum \mathrm{Y}^{2}-\left(\sum \mathrm{Y}\right)^{2}\right\}}} \\
& = \\
& \frac{8(227450)-(457)(3820)}{\sqrt{\left\{8.27443-(457)^{2}\right)\left\{8.1982400-(3820)^{2}\right\}}} \\
& = \\
& \frac{1819600-1745740}{\sqrt{(219544-208849)(15859200-14592400)}} \\
& =\frac{73860}{\sqrt{(10695)(1266800)}} \\
& =\frac{73860}{\sqrt{13548426000}} \\
& =\frac{73860}{116397,7061629653}=0,634
\end{aligned}
$$

Setelah dilakukan perhitungan maka diperoleh hasil koefisien korelasi sebesar 0,634 bearti terdapat hubungan antara variabel harga terhadap volume penjualan besi pada PT. Inti Logam Palembang dengan tingkat hubungan yang kuat.

Dari perhitungan koefisien korelasi diatas maka dapat disimpulkan bahwa hubungan yang ditimbulkan antara penetapan harga terhadap volume penjualan besi pada PT. Inti Logam Palembang adalah kuat dan positif yaitu sebesar 0,634 yang berada pada interval $(0,60-0,799)$, sehingga terdapat hubungan antara penetapan harga terhadap volume penjualan besi artinya penetapan harga berpengaruh terhadap volume penjualan.

\section{Pengujian Hipotesis}

Untuk mengetahui apakah hipotesis diterima atau ditolak maka akan dilakukan uji Hipotesis dengan menghitung harga statistik " $\mathrm{t}$ " atau $\mathrm{t}$ hitung dengan langkah-langkah sebagai berikut :

1. Ditentukan Hipotesis nol (Ho) dan Hipotesis Alternatif $(\mathrm{H} 1)$

2. Hitung harga statistik pengujian "t" dengan rumus sebagai berikut :

$\mathrm{t}_{\text {hitung }}=\frac{r \sqrt{n-2}}{\sqrt{1-r^{2}}}$

3. Tentukan taraf nyata (a) yaitu $a=$ 0,05

4. Tentukan harga t tabel berdasarkan taraf signifikan dan derajat kebebasan tertentu. Harga tabel dengan menggunakan rumus sebagai berikut :

$\mathrm{t}_{\text {tabel }}=\frac{\alpha}{2} D f(n-2)$

5. Kesimpulannya yaitu :

- $\mathrm{H}_{\mathrm{o}}$ ditolak dan $\mathrm{H}_{\mathrm{i}}$ diterima apabila t-hitung $>$ dari t-tabel

- $\mathrm{H}_{0}$ diterima dan $\mathrm{H}_{\mathrm{i}}$ ditolak apabila t-hitung $<$ dari t-tabel

Berdasarkan langkah-langkah diatas, dapat dicari nilai $\mathrm{t}$ hitung dan $\mathrm{t}$ tabel dari data yang diperoleh :

1. Menentukan Hipotesis

Ho : Tidak ada pengaruh yang signifikan antara penetapan harga terhadap volume penjualan besi pada PT. Inti Logam Palembang. 
$\mathrm{H} 1$ : Ada pengaruh yang signifikan antara penetapan harga terhadap volume penjualan besi pada PT. Inti Logam Palembang.

2. Menentukan harga statistik pengujian " $\mathrm{t}$ " dilakukan untuk mengetahui ada tidaknya pengaruh yang signifikan terhadap variabel $x$ dan $y$,maka harga $t$ hitung adalah sebagai berikut :

$$
\begin{aligned}
t_{\text {hitung }} & =\frac{r \sqrt{n-2}}{\sqrt{1-r^{2}}}=\frac{0,634 \sqrt{8-2}}{\sqrt{1-0,634}} \\
& =\frac{(0,634) \sqrt{6}}{\sqrt{0,366}}=\frac{(0,634)(2,449)}{0,604} \\
& =\frac{1,552666}{0,604}=2,570
\end{aligned}
$$

3. Tentukan harga t tabel berdasarkan taraf signifikan dan derajat kebebasan tertentu.

$$
\begin{aligned}
\mathrm{t}_{\text {tabel }} & =\frac{\alpha}{2} D f(n-2)=\frac{0,05}{2} D f(8-2) \\
& =0,025 D f(6)=2,447
\end{aligned}
$$

Menurut Riduan dan Akdon (2009:125) jika $\mathrm{H}_{\mathrm{o}}$ ditolak dan $\mathrm{H}_{\mathrm{i}}$ diterima apabila $t_{\text {-hitung }}>$ dari $t_{\text {-tabel }}$ sebaliknya jika $\mathrm{H}_{0}$ diterima dan $\mathrm{H}_{\mathrm{i}}$ ditolak apabila $\mathrm{t}$-hitung $<$ dari $\mathrm{t}$-tabel. Pada penelitian ini dapat diketahui bahwa thitung $(2,570)>t_{\text {tabel }}(2,447) \quad$ Pada kondisi ini maka $\mathrm{Ho}$ ditolak dan $\mathrm{H}_{\mathrm{i}}$ diterima sehingga dapat disimpulkan ada pengaruh yang signifikan antara penetapan harga $(X)$ terhadap volume penjualan besi (Y) pada PT. Inti Logam Palembang.

\section{Koefisien Diterminasi}

Untuk menyatakan besar kecilnya sumbangan variabel $X$ terhadap $Y$ dapat ditentukan dengan rumus koefisien diterminan (Riduan dan Akdon 2009:124) sebagai berikut :
$K P=r^{2} \times 100 \%$

Dimana :

$\mathrm{KP}=$ Nilai Koefisien Diterminan

$\mathrm{R}=$ Nilai Koefisien Korelasi

$\mathrm{KP}=0,634^{2} \times 100 \%$

$\mathrm{KP}=0,401956 \times 100 \%$

$\mathrm{KP}=40,1956 \%$

Berdasarkan

perhitungan koefisien diterminasi diatas diperoleh nilai sebesar 40,1956 \% dari variabel volume penjualan $(\mathrm{Y})$ dipengaruhi oleh variabel penetapan harga $(X)$ dan sisanya sebesar $59,804 \%$ dipengaruhi oleh variabel lain diluar harga.

\section{H. Pembahasan}

PT. Inti Logam Palembang merupakan salah satu perusahaan yang menjalankan aktivitasnya di bidang perdagangan umum khususnya perdagangan berbagai jenis besi, seperti Plat, Pipa, Behel, IWF, UNP, CNP, Wiremesh, As dan lain-lain, akan tetapi peneliti tertarik untuk meneliti tentang besi behel ukuran $8 \mathrm{~mm}$ dan $10 \mathrm{~mm}$ dengan jenis KS-Cilegon karena besi behel merupakan bahan bangunan yang selalu digunakan dan dibutuhkan.

Hasil analisis regresi linier sederhana menunjukkan persamaan $Y$ $=82,994+6,906 \mathrm{X}$ ini menunjukkan terdapat pengaruh antara penetapan harga $(X)$ terhadap volume penjualan (Y) adalah positif dan kuat.

Sedangkan hasil analisis koefisien korelasi yaitu sebesar 0,634. Artinya nilai koefisien korelasi menunjukkan terdapat hubungan yang ditimbulkan antara penetapan harga terhadap volume penjualan besi pada PT. Inti Logam Palembang adalah kuat dan positif. Sehingga dapat disimpulkan bahwa hubungan yang ditimbulkan antara penetapan harga terhadap volume penjualan besi pada PT. Inti Logam Palembang adalah kuat dan positif yaitu sebesar 0,634 yang berada pada interval $(0,60-0,799)$, sehingga 
terdapat hubungan antara penetapan harga terhadap volume penjualan besi artinya penetapan harga berpengaruh terhadap volume penjualan.

Berdasarkan analisis koefisien diterminasi yang dilakukan sebesar $40,1956 \%$ penjualan dipengaruhi oleh harga sedangkan sisanya yaitu 59,804 $\%$ dipengaruhi oleh variabel lain yaitu produk, distribusi, dan promosi.

Dalam memasarkan suatu produk baik barang maupun jasa, faktor lain seperti produk, distribusi, dan promosi sangat penting untuk dipertimbangkan karena semua itu dapat mempengaruhi permintaan akan barang atau jasa yang dijual oleh perusahaan. Produk yang bermutu dan bekualitas baik akan mempengaruhi konsumen dalam mempertimbangkan untuk membeli barang tersebut, kemudian dalam proses pendistribusian barang tersebut juga harus lancar dan juga harus menjangkau wilayah yang belum terjangkau dan dalam hal ini bidang promosi berperan untuk menyampaikan dan mengenalkan produk yang akan dipasarkan tersebut kepada konsumen sehingga para konsumen tertarik untuk membeli. Jadi antara produk, harga, distribusi, promosi, dan mutu sangat berkaiatan erat dan menunjang satu sama lain dalam proses pemasaran sehingga tujuan utama perusahaan yaitu memperoleh laba yang sebesarbesarnya dapat tercapai dengan baik.

Berdasarkan hasil pengujian hipotesis diperoleh nilai $t_{\text {hitung }}=2,570$ lebih besar dibandingkan dengan $t_{\text {tabel }}$ $=2,447$ dengan tingkat kesalahan 0,05 . Dengan demikian $t$ hitung lebih besar dari t tabel $(2,570>2,744)$ maka keputusannya menolak hipotesis nol (Ho) dan menerima hipotesis alternatif (Hi) berarti ada pengaruh antara penetapan harga $(X)$ tehadap volume penjualan (Y) pada $\mathrm{PT}$. Inti Logam Palembang.

\section{Kesimpulan dan Saran \\ 1. Kesimpulan}

Kesimpulan yang diambil dari penelitian tentang Pengaruh Penetapan Harga terhadap Volume Penjualan Besi Pada PT. Inti Logam Palembang sebagai berikut :

a. Berdasarkan analisis regresi linier sederhana pada besi didapat persamaan $\mathrm{Y}=82,994+6,906 \mathrm{X}$ maka terdapat pengaruh variabel harga $(X)$ terhadap volume penjualan $(\mathrm{Y})$.

b. Hubungan antara harga terhadap volume penjualan sangat erat atau signifikan. Berdasarkan perhitungan statistik maka diperoleh nilai koefisien korelasi 0,634 ini menunjukkan hubungannya sangat kuat dan positif.

c. Dilihat dari uji hipotesis dengan taraf signifikan 5\% maka $t$ hitung lebih besar dari t tabel ( $t_{\text {hitung }} 2,570>t_{\text {tabel }}$ 2,447). Pada kondisi ini maka Ho ditolak dan $\mathrm{H} 1$ diterima sehingga dapat disimpulkan bahwa ada pengaruh yang signifikan antara harga terhadap volume penjualan. Dilihat dari nilai koefisien korelasi $(r)$ $=0,634$. Harga koefisien diterminasi $\left(r^{2}\right)=0,401956$ dapat diartikan bahwa 40,1956\% dari volume penjualan besi pada PT. Inti Logam Palembang dipengaruhi oleh harga yang ditetapkan, sedangkan sisanya dipengaruhi oleh faktor lain yaitu produk, distribusi, dan promosi.

\section{Saran}

Berdasarkan simpulan yang telah dikemukakan sebelumnya, maka penulis mencoba memberikan saran yang diharapkan dapat dijadikan bahan masukan bagi PT. Inti Logam Palembang masa yang akan datang untuk meningkatkan volume penjualannya. Adapun saran-saran tersebut adalah sebagai berikut:

a. PT. Inti Logam Palembang dalam menetapkan harga besi dari bulan 
ke bulan tidak terlalu besar sehingga penurunan jumlah penjualannya pun sedikit dan pangsa pasarnya juga dapat dipertahankan. Jadi sebaiknya perusahaan dapat mempertahankan harga agar jumlah penjualannya dapat meningkat.

b. Perusahaan juga harus melakukan kegiatan penjualan lebih genjar lagi dan memperhitungkan bagaimana cara meningkatkan laba untuk setiap ukuran dan jenis besi behel yang akan dijual.

\section{DAFTAR PUSTAKA}

Alma, Buchari, 2009. Manajemen Pemasaran dan Pemasaran Jasa, Alfabeta, Bandung.

Bungin, Burhan, 2010, Metodelogi Penelitian Kuantitatif Komunikasi, Ekonomi, dan Kebijakan Publik serta IImu-IImu Sosial Lainnya, Edisi Pertama, Kencana, Jakarta.

Kotler \& Gary Amstrong, 2012. PrinsipPrinsip Pemasaran, Edisi Ketiga Belas, Erlangga, Jakarta.

Kotler \& Kaller, 2009. Manajemen Pemasaran, Edisi Ketiga Belas, Indeks, Jakarta.

Riduan \& Akdon, 2009. Rumus dan Data dalam Analisis Statistik. Alfabeta, Bandung.

Sugiyono. 2009. Metode Penelitian Bisnis. Alfabeta Bandung.

Swastha, Basu, DH, 2010. Manajemen Penjualan, BPFE, Yogyakarta.

Swastha, Basu, 2009. Manajemen Penjualan, Edisi Ketiga, BPFE, Yogyakarta.
Swastha, Basu dan Irawan, 2008. Manajemen Pemasaran Modern, Liberty, Yogyakata.

Soemarso, 2009. Akuntansi Suatu Pengantar 1, Edisi Kelima, Salemba Empat, Jakarta. 